Volume 12(2): 247-273

\title{
The Merger Storm Recognizes No Borders: An Analysis of Media Rhetoric on a Business Manoeuvre
}

\author{
Marja-Liisa Kuronen, Janne Tienari and Eero Vaara
}

Helsinki School of Economics, Finland, Lappeenranta University of Technology, Finland, and Swedish School of Economics and Business Administration and Ecole de Management de Lyon, France

\begin{abstract}
Despite the central role of the media in contemporary society, studies examining the rhetorical practices of journalists are rare in organization and management research. We know little of the textual micro strategies and techniques through which journalists convey specific messages to their readers. Partially to fill the gap, this paper outlines a methodological framework that combines three perspectives of text analysis and interpretation: critical discourse analysis, systemic functional grammar and rhetorical structure theory. Using this framework, we engage in a close reading of a single media text (a press article) on a recent case of industrial restructuring in the financial services. In our empirical analysis, we focus on key arguments put forward by the journalists' rhetorical constructions. We maintain that these arguments-which are not frame-breaking but rather tend to confirm existing presuppositions held by the audience - are an essential part of the legitimization and naturalization of specific management ideas and ideologies.
\end{abstract}

Key words. discourse; legitimization; media; restructuring; rhetoric

The media are a crucial contemporary social arena for practising the art of rhetoric. Journalists' acts of convincing and persuading their readers in specific contexts constitute an important research topic. This is particularly timely in relation to neo-liberalism as a political project for the restructuring and rescaling of social relations in accord with the demands of an unrestrained global capitalism. Scholars such as Pierre Bourdieu and Norman Fairclough have critically highlighted the importance of language and semiosis in the continuous construction and reconstruction of the neo-liberal global order. Through an in-depth look at media rhetoric in the cross-border merger context, we attempt to follow in their footsteps. 
It seems that the role and influence of the media have been discovered quite recently in organization and management research. Mazza and Alvarez (2000) provide an important contribution by examining texts in nationwide newspapers and magazines in relation to the transfer and dissemination of a particular management idea. They argue that the popular press is an important arena where the legitimacy of management ideas and practices is (re)produced. Media texts have also been identified as critical sites where the (re)construction and legitimization of organizational change such as mergers and acquisitions are carried out through specific discourses (Vaara and Tienari, 2002) and discursive practices (Hellgren et al., 2002). It would seem that the rhetorics and rhetorical choices of journalists play an important role in the construction of meaning around business manoeuvres.

Studies examining the rhetorical practices of journalists are, however, rare in organization and management research. In particular, we know little of the textual micro strategies and techniques through which journalists convey specific messages to their audiences. Partially to fill this gap, this paper has two aims: (1) to outline a theoretically grounded methodological framework that can be used by organization theorists to analyse the micro strategies and techniques in the rhetorics of journalists; and (2) to apply this framework to illustrate how journalists make use of various rhetorical means in their argumentation.

Our theoretical framework combines critical discourse analysis (Fairclough, 1992, 1995, 1997), systemic functional grammar (Halliday, 1978, 1994; Eggins, 1994; Martin, 2000) and rhetorical structure theory (Mann and Thompson, 1988; Mann et al., 1992). We suggest that this three-fold framework provides an opportunity to engage in a process of analysis where the prominent discourse types in a text, the strategic meaningmaking functions within these discourse types, and key rhetorical choices and strategies working to persuade and convince the reader can all be coherently explored. Such analysis allows us to argue which discourses become legitimized in media texts and how this legitimization is carried out by journalists.

To show how journalists make use of specific rhetorical strategies and techniques, we focus on a recent case of international industrial restructuring in financial services. The case is the merger between the Finnish- Swedish MeritaNordbanken and the Danish Unidanmark. We examine in detail a two-page textual collage that appeared under the heading 'Nordic Union Bank complete but for Norway' in Talousel "am"a, the leading Finnish business weekly, in March 2000 (see the appendix for the English translation). At the time, the Danish 
company had just joined the Swedish and Finnish companies in the bank group, and speculation about the Norwegian company, which was eventually acquired in autumn 2000, continued.

We chose this particular article because it is a typical example of media coverage of international industrial restructuring. This allows us to illustrate the processes and practices through which journalists construct images of specific cases and put forward more general ideas and ideologies around industrial restructuring. In our empirical analysis, we focus on the following rhetorical constructions: (1) industrial restructuring is inevitable, (2) core business thinking is the appropriate restructuring strategy, (3) the restructured company faces specific future challenges, (4) international confrontation is taking place, and (5) personal power battles are an essential part of restructuring. These rhetorical constructions can be seen as key arguments put forward by the journalists. The point is that such arguments-which are not frame breaking but rather tend to confirm existing presuppositions held by the audienceare an essential part of the legitimization and naturalization of specific management ideas and ideologies.

\section{A Theoretical Framework for Analysing Media Texts}

In our view, rhetorical analysis holds great promise in organization and management research. In contrast to more mainstream theorizing, 1 management ideas and/or organizing principles can be put under critical scrutiny. For example, the rhetoric of human resource management has been examined in seminal works (Gowler and Legge, 1983; Legge, 1995) and extended to a more general model of rhetorics of organizational control (Linstead, 2001). The discursive constitution and 'underlying' rhetorical strategies of management concepts have been made explicit in a number of contributions (see e.g. Alvesson, 1993; Berglund and Werr, 2000; Case, 1999; Kamoche, 1995). Also, as Watson (1995) has aptly shown in the case of a casual dialogue between two managers, seemingly banal texts can be understood as 'more than just a matter of surface play of language'; there are interests at work in the broader processes of which individual texts are part (Watson, 1995: 816). While these studies have examined (explicitly or implicitly) how rhetorics play an essential role in the legitimization of various management ideas and practices, they have not paid attention to the power of media and the rhetorics of journalists in these processes. Therefore, in the following, we attempt to outline a theoretical framework for this purpose. 
Our starting point is that journalists survive by gaining the interest of their audience. Sociologists have argued that this often means the reproduction of commonly held ideas and ideologies. Bourdieu (1998) calls these 'commonplaces' that 'work' because everyone can take them in immediately and their very banality makes them something the speaker (journalist) and the audience (readers) have in common. Linguists have also emphasized the close connection with the audience-in media and elsewhere. In the context of the so-called New Rhetoric, Perelman and Olbrechts-Tyteca put it as follows: 'It is in terms of audience that an argumentation develops' (1971: 5). Consequently, the rhetorical strategies and practices of journalists are always conditioned, whether consciously or unconsciously, by the people the writer wishes to address.

This means that journalists' rhetorical skills are crucial when attempting to establish contact with readers. Studying the rhetorical strategies and practices of journalists, however, requires a theoretical and methodological framework that enables us to focus on specific rhetorical elements. In our view, a combination of critical discourse analysis, systemic functional linguistics and rhetorical structure theory forms a meaningful framework for this purpose. This is because it allows us to engage in critical reading that is grounded in the textual analysis of strategic meaning-making functions (systemic functional linguistics) and concrete rhetorical structures in specific textual totalities (rhetorical structure theory).

\section{Critical Discourse Analysis}

Diverse approaches in discourse analysis have become increasingly popular in social sciences. Critical discourse analysis (CDA) has gained ground, especially among researchers who have examined the power and ideological implications of specific discourses. Following Norman Fairclough's (1992) critical discourse analysis, we consider discourses as an inherent part of sociocultural practices that are embedded in social contexts. We view discourses as both socially conditioned and socially constitutive, and set out to analyse how texts work within sociocultural practice (Fairclough, 1997).

The question of discourse type is central in critical discourse analysis because it provides the framework that determines what is taken as legitimate and natural. In critical discourse analysis, discourse types are closely linked with ideologies (see Fairclough, 1997). On the one hand, by creating and maintaining social reality and order, specific discourses necessarily support particular ways of thinking that promote specific ideas and practices 
while marginalizing others. On the other hand, the roots of specific discourses can also be traced to particular worldviews and even political projects. For example, Fairclough (2000) speaks of the discourse of 'global capitalism' as a discourse that carries with it a certain neoliberal political ideology.

In the context of the media coverage of mergers and acquisitions, Vaara and Tienari (2002) argue that 'rationalistic' discourse — a variant of the discourse on global capitalismdominates the order of discourse (see Fairclough, 1997). It works through specific themes (such as competitiveness and efficiency) and voices (actors such as corporate managers enrolled as subjects) to convince the reader of the justification and legitimacy of specific merger or acquisition decisions and the related management practices. In so doing, rationalistic discourse can be argued to render the logic of the contemporary neo-liberal global economy 'factual' (see Fairclough, 2000). There are, however, also other discourses that play a central role in mergers and acquisitions. For example, the studies by Risberg et al. (2003) and Hellgren et al. (2002) have shown how 'nationalistic' discourse is frequently used when making sense of international mergers and acquisitions and their ramifications.

In the media, implicit, taken-for-granted assumptions - or presuppositions - are an inherent part of the discourses. It is on these presuppositions that the orderliness and coherence of texts rest (Fairclough, 1997). These assumptions tell us something about the speaker's (journalist) expected relation between him/herself and the audience (readers). In a sense, they are essential discursive building blocks for effective communication. It is also important to note that individual texts are 'incomplete' in the sense that meanings become available for readers only when they connect texts to other texts. Intertextuality is thus a crucial element in the framework outlined here; in addition to its linguistic dimension, textual evidence is a matter of how links between one text and other texts and text types are inscribed in the surface of the text (Fairclough, 1997). Interpretations of which themes and voices become marginalized and excluded, for example, are likely to be possible only through reflection on what 'should have been' articulated or present in the text but was not for some particular reason.

To understand the concrete practices and techniques that are employed in constructing specific ideas, however, we need micro-level analysis. Therefore, methods for detailed linguistic analysis need to be introduced into the research framework. In developing his programme of critical discourse analysis, Norman Fairclough has been influenced among 
others by the work of M. A. K. Halliday. As Martin (2000: 275, referring to Fairclough, 1997) argues: 'systemic functional linguistics is a congenial theory for critical discourse analysis because it is multifunctional, well adapted for text analysis and concerned with relating language to social context.'

\section{Systemic Functional Grammar}

Systemic functional grammar is based on the tradition of European functional theory (Halliday, 1978, 1994).2 Systemic functional linguistics enables us to interpret the meaning potential of texts. It enables us to address, first, how the text constructs the world of experience; second, how it negotiates its desired meanings with the reader; and, third, how its textual architecture contributes to the interpretation of its coherence. The point of departure in systemic functional analysis is the genre of the text. In written media, for example, the distinction between genres of news ('what really happened') and non-news (reports or comments) has traditionally been crucial.

Halliday's (1978) theory is functional and semantic rather than formal and syntactic. The focus is on authentic products of social interaction, that is, on texts considered in relation to the cultural and social context in which they are negotiated and in which they function. It is functional in its interpretation of texts, of the system 3 and of the elements of linguistic structures. The basic assumption of the theory is that the meanings of a language are construed by two functional components: ideational (or experiential) and interpersonal metafunctions. The third metafunction, textual, gives relevance to the other two. The experiential metafunction relates to the world of experience, the interpersonal to relations between writer and reader, and the textual to the 'texture' of a text, which is seen as an organized object.

Further, language is examined as a system of meanings, not as a system of linguistic structures (vocabulary; grammar). The function of linguistic structures is to realize meanings. Halliday's (1978) basic assumptions and principles lead to the analysis of textual totalities rather than linguistic constructions such as sentences or clauses. This approach interprets the linguistic system functionally. It interprets how language is structured for use. Language is interpreted as a system of forms to which meanings are attached (Halliday, 1994). Systemic functional theory thus provides tools to understand why a text means what is does and why it is valued as it is. The theory renders possible the explanation of variations of choice. 
In sum, systemic functional linguistics is a useful descriptive and interpretive framework for viewing language as a strategic meaningmaking resource (Eggins, 1994). As Martin (2000: 275) puts it: 'For many, one of its real strengths in the context of critical discourse analysis work is its ability to ground concerns with power and ideology in the detailed analysis of texts as they unfold, clause by clause, in real contexts of language use (including the analysis of multi-modal texts involving pictures and diagrams) (e.g. Kress and van Leeuwen 1996: 27; O’Toole 1994).'

\section{Rhetorical Structure Theory}

To understand processes of legitimatization in a media text, we need to trace the means by which journalists can influence their audience at the level of the organization of their ideas. We add elements of rhetorical structure theory (RST) to our framework in order to describe structures and functions in a journalist's interaction with a potential audience and ultimately to understand the journalist's purpose(s) (Mann and Thompson, 1988; Mann et al., 1992). Mann et al. (1992) introduce RST as a form of discourse analysis that provides a detailed description of two properties of language: how language can be used to communicate and how it contributes to the outcomes of interactions. It is a framework for describing rhetorical relations among parts of a text—within a clause and beyond.

The coherence of textual communication is a key concept in rhetorical structure theory (Mann et al., 1992; Mann and Thompson, 1988). As a formulation, coherence means that for every part of a text there is a function, some plausible reason for its presence, which is evident to the audience. RST assigns a status to every part of the text. Coherence refers to the reader's sense that no parts are missing in conveying the message of the text.

According to RST, there are various sorts of 'building blocks' that can be observed to occur in texts. These blocks, or units of structures, are at two levels. The principal level deals with nuclearity and relations (or the coherence relation). The second level of structures is called schemas. The most frequent structural pattern includes two spans of text that are related; one of the units of a text has a specific relation to the other. For example, a claim may be followed by evidence for the claim. RST posits in this case an evidence relation4 between the two spans. In the comparison, the claim is more essential to the text. For that reason, in RST it is called a 'nucleus' and the evidence span a 'satellite'. The order of the spans is not constrained. 
Text-structuring relations are always functional. They produce certain categories of effects. Relations can be described in terms of the purposes of the speaker (journalist), the speaker's assumptions about the readers, and certain propositional patterns in the subject matter of the text (Mann, 1999). RST helps to impute particular desires for particular effects to the speaker. It helps to explain why particular uses of language were chosen. Also, it enables consideration of and argumentation on why particular uses of language can be interpreted to have succeeded or failed (Mann and Thompson, 1988; Mann et al., 1992).

As a tool of rhetorical analysis, RST is pre-realizational. It makes statements about how meanings and intentions are structured and combined, but not about how they are realized in language use (Mann et al., 1992). For this reason, we analyse the article by means of both the concepts of RST and those of systemic functional grammar, which, in turn, focuses on linguistic and other semiotic choices, that is, realizations in language use.

\section{Summary of the Framework}

In order to build a well-grounded view on convincing and persuading in a media text, we have proposed a three-part methodological framework. A crude illustration of this framework is provided in Figure 1. In our analysis, we interpret discourse types in the text (i.e. 'rationalistic' and 'nationalistic') and give evidence of how the text offers the readers its claim(s) within discourses. The question of 'how' is approached from two perspectives: language use (systemic functional grammar) and rhetorical relations (rhetorical structure theory). The linguistic component in the analysis contributes to the tracing of the interpretation process of the reader. Focusing on the linguistic and rhetorical choices made by the journalists, we can make explicit the assumptions of discourses embedded in the messages conveyed. We approach the text systematically by close reading. Analysis by transitivity system (ideational metafunction), mood system (interpersonal metafunction) and theme system (textual metafunction) indicates such detail, precision and explicitness (see Martin, 2000). We thereby provide evidence for the interpretation of the meaning potential of the textual totality.

\section{'Nordic Union Bank Complete but for Norway'}

We focus on an article that appeared under the main heading 'Nordic Union Bank complete but for Norway" in Talousel "am"a, the leading Finnish weekly business magazine, in March 2000. The article consists of pieces of commentary on the making of a financial services 
group that currently operates under the name Nordea. The core of Nordea now consists of a Swedish (ex-Nordbanken), Finnish (ex-Merita Bank), Danish (ex-Unidanmark) and Norwegian (ex-Christiania Bank og Kreditkasse) financial services company. When the article was published, Unidanmark had just joined the bank group and speculation about the acquisition of Kreditkassen continued. Kreditkassen was eventually acquired in autumn 2000.

Figure 1. The Theoretical Framework.

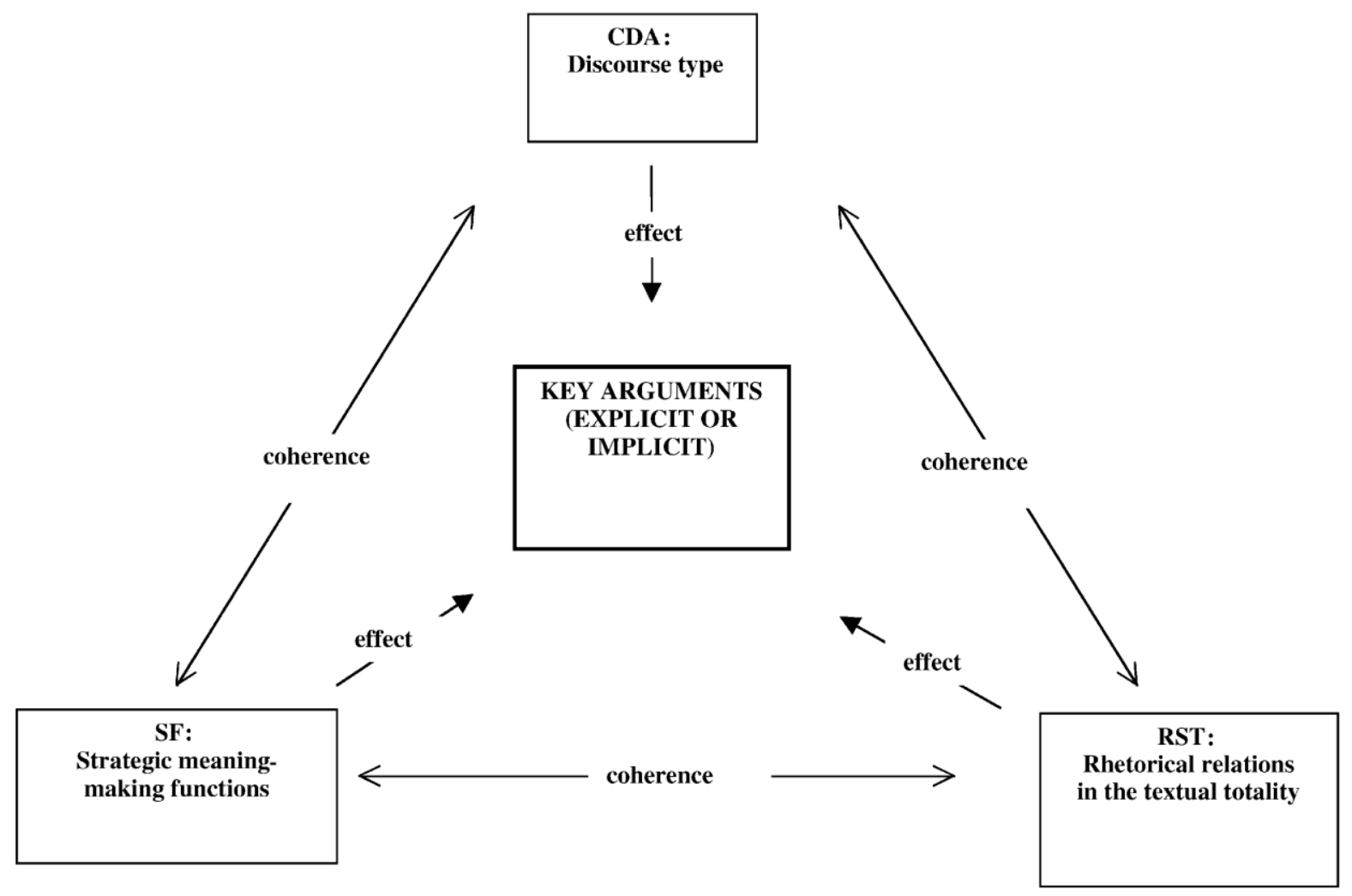

Throughout our analysis, we consider the two-page 'collage' as a textual totality; everything therein has a purpose or function that contributes to constructing its main claim(s) (see the appendix for the English translation). Two journalists' names appear as writers: Esko Rantanen and Matti Kankare. The audience is the readership of a weekly business magazine - presumably this also includes Finnish managers and employees of the bank group. There are two bundles of texts in the article. The body of the article is the longest text in the two-page totality (the nucleus in the RST framework; Mann and Thompson, 1988). The body is accompanied by the highlighted co-text and picture of top managers, and by the column at the bottom of the two-page totality, together with the picture of a customer at an ATM (automatic teller machine). Together, these bundles of texts convey meanings that are of interest in regard to convincing and persuading. 
Our analysis has proceeded 'bottom up'-from the micro text to how the text works within sociocultural practice. We began by analysing the meaning potential of the text in terms of metafunctions using systemic functional grammar; we went on to identify the rhetorical structures and relations of the units of the article (persuading and convincing the reader vis-'a-vis the strategic meanings), and identified key discourse types in the article using critical discourse analysis. After these stages, the analysis proceeded iteratively, in a sense 'sharpening' the picture through several rounds of reading.

Based on our analysis, we were able to identify five particularly salient rhetorical constructions in the two-page 'collage': (1) industrial restructuring is inevitable, (2) core business thinking is the appropriate restructuring strategy, (3) the restructured company faces specific future challenges, (4) international confrontation is taking place, and (5) personal power battles are an essential part of restructuring. These rhetorical constructions can be seen as key arguments put forward by the journalists.

\section{The Rhetorical Construction of the Key Arguments}

\section{Industrial Restructuring Is Inevitable}

The article rhetorically constructs international restructuring as inevitable in the financial services industry. The body of the article, with accompanying texts and picture, conveys the meaning of a dynamic process of mergers in Europe. The message seems clear: mergers are natural and there are no major problems in this particular Nordic constellation (except those caused by the Danes). The column at the bottom takes a slightly more questioning stance; the journalist engages in a discussion with the top managers of the bank group, contrasting the strategic definitions of the bank's policy with his own views. The two texts make contact with the reader by partly different means. Interpretations based on the transitivity system (see Halliday, 1994) reveal that the idea of a dynamic process is mediated mostly by material processes. Recurrent processes are 'buy', 'create', 'will join', 'acquire', and 'take control of':

The markets are increasingly confident that Norway's Kreditkassen will join the Swedish-Finnish-Danish financial group.

Last December Unidanmark bought the Norwegian general insurance company Vesta ... SE-Banken acquired Trygg-Hansa . . It's possible that before long we may see If buying up the general insurance business of the joint Nordic bank. 
Verbal processes describe merging as a dynamism: Unidanmark has already joined, whereas Kreditkassen 'will join' later on. Kreditkassen has not yet been 'taken control of'. The participants in the processes are banking and insurance companies. Rhetorically, and in conveying the meaning of a dynamic process, the highlighted co-text is important. It strengthens the interpretation of mergers as a natural phenomenon-a 'storm' - that is inevitable in the global world of finance. Numerous examples work to convince the audience of the necessity of merging and contribute to their taken-for-grantedness. Mergers thus become naturalized (see Fairclough, 1995; Vaara and Tienari, 2002). There are, however, evidently some banks that are still 'struggling to remain independent'. The verb struggle implies that it is hard to remain independent when the forces of nature are raging. The circumstances of processes, especially time adjuncts, are notable in this particular text; one company bought another 'in February' or 'last autumn' and another company underwent a major profitability crisis 'in the early '90s'. History gives direction for the future.

The point of departure here is that, through metaphoric expressions such as 'a storm of banking and insurance mergers' in the first sentence of the main text and the heading 'Bank mergers no longer recognize borders' of the highlighted co-text, cross-border mergers can be interpreted to be (re)constructed as inevitable and unavoidable phenomena in a new global order. This business-driven order-where borders no longer matter and where the weak will fall-is not questioned in any way. Managerial action contributing to the 'sound' control and coordination of crossborder mergers in the global order, then, becomes legitimized. The purpose of the highlighted co-text is evidently to justify - through a list of apparently 'real' examples - the 'fact' that the formation of multinational companies is growing in the financial services industry. In so doing, the text is explicitly and apparently purposefully based on nations and nationalities: 'Germany's', 'US', 'Spanish', 'Portuguese', 'Royal Bank of Scotland', 'German', 'French', 'French', 'Dutch', 'German', 'Den Danske Bank' ( The Danish Bank), 'Norwegian'.5

From the perspective of rhetorical structures, the text 'Bank mergers no longer recognize borders', highlighted in green in the original article, is an essential attachment to the body text. Its relation to the body is that of circumstance. When 'a storm of . . mergers is raging across Europe', it is difficult for companies 'struggling to remain independent', especially those that 'underwent a major profitability crisis'. In the case of the relation of circumstance (see Mann, 1999), the nucleus expresses events or ideas occurring in the 
interpretive context, in our case 'a storm of mergers'. The (highlighted) satellite thus gives an interpretive context of situation or time-mergers took place all over Europe in the 1990s. The style of reporting, listing numerous cases with place and time adjuncts, gives an impression of a process that is not complete. The examples chosen by the journalist also shed light on situations in which mergers might occur in the future.

Another relation that can be observed between the body and the highlighted text is evidence (see Mann, 1999). There is a claim (expressed in the nucleus) that is affirmed by information intended to convince the reader. There may be an associative connection between the metaphor of 'storm' and the great number of mergers listed in the highlighted text. It may also be concluded that the co-text is intended to prove that larger units in banking are a necessity, and possibly also that, if banks in the Nordic countries do not merge, financial giants elsewhere may be interested in acquiring them. On the whole, this particular text widens the perspective from the Nordic countries to Europe. In the highlighted text, the writer tries to convince by presenting evidence of the claim that a merger has in many cases been a matter of survival. Further, we can here see argumentation by quantity (see Perelman, 1977/1996) — a relatively long list of 'real' examples. According to this kind of reasoning, quantity is a sustainable argument.

\section{Core Business Thinking Is the Appropriate Restructuring Strategy}

In addition to the meanings of a dynamic, inevitable process of international industrial restructuring, there is another dominating meaning to be interpreted in the body of the article. A distinct form of 'financial supermarket' 6 is the core of the rationalistic discourse type in the present context. This interpretation is based, on the one hand, on the choice of relational processes ( $\mathrm{x}$ is something), and, on the other, on the mood system and modality (see Halliday, 1994). Meanings related to a financial supermarket have been construed mainly within the framework of interpersonal metafunction (mood and modality). This means that the writer may have wanted to safeguard the transferring of one of his core messages to the reader. The entire modality apparatus is crucial in construing the financial supermarket in this particular merger context (modal expressions are in italics below): 
The Danes should not be provoked just yet with talk of selling general insurance, because Unidanmark actually used general insurance as a means to puff itself up to the level of MeritaNordbanken and thus obtain a 30 per cent share of the joint financial group.

There'll certainly be plenty of work ahead for the financial giant when it raises the number of on-line customers at Unidanmark from the present 170,000 to well over one million.

Relational processes are crucial in conveying the meaning of the essence of the business of a financial supermarket. By definition, relational processes declare things as indisputable facts. This is the case even for the opinions of the writer: 'It is clear that the Norwegian Kreditkassen will join MeritaNordbanken and Unidanmark.' This statement is very definite, and it is positioned at the beginning of the headnote. We get the basis for this opinion only at the very end of the article: it is 'the markets' that are increasingly confident about the case. The clause 'it is clear' is attitudinal. It thereby makes contact with the reader; it is interpersonal.

In defining the core business of a financial supermarket, it is also worth observing the qualifiers and identifiers in relational processes. This section of the body of the article in particular comes to define the genre of news not just as 'objective' reporting but also as speculation:

The business concept behind the merger is less clear, however: last December Unidanmark bought the Norwegian general insurance company Vesta. General insurance is an odd business for a financial group specialising in financing and investment services ...

The global trend has long been to separate life and general insurance into completely different companies. It's possible that before long we may see If buying up the general insurance business of the joint Nordic bank.7

Between these two sections, examples are given that argue for the statements. Rhetorically, the construction of analogy is obvious. Statements by means of relational processes are followed by a metaphoric description of certain businesses that do not seem to fit in a financial supermarket: 'In the Nordic banking and insurance acquisitions of recent years, 
general insurance has customarily flown out'; 'But even here, life and general insurance did not fit under the same roof'. The interpretation of analogy is confirmed by the modal adjunct of usualness ('customarily') and by the circumstance of the process of 'flowing out' (in the Nordic banking and insurance acquisitions of recent years). Further, earlier on in the above section the expressions in italics ensure the interpretation: 'The global trend has long been to separate . . . into completely different companies'. The choice of the metaphor 'flowing out' is important. General insurance has not been sold, for example; rather, it has 'flown out', without an outside agent, without the implication that someone threw it out. This, again, hints at an apparently natural phenomenon.

In the present context, it may be interpreted that the questionable general insurance theme breaks the overall image of coherence within the rationalistic discourse type. In the body of the article, journalist Esko Rantanen portrays general insurance as the only problematic factor in constructing a sound Nordic financial supermarket. He does this repeatedly by, for example, referring to decisions taken in earlier mergers and acquisitions in the sector. Thorleif Krarup, the CEO of Unidanmark, appears here in the role of reminding the reader that it is the 'fair' financial rationale that will decide the fate of the business in the financial supermarket's overall portfolio. The journalist himself, however, hints at political power games-particularly from the Danes in the merger negotiations - as a potential hindrance to the fulfilment of the financial rationale. Further, in the column below the main body text, journalist Matti Kankare writes that (1) Unidanmark will add general insurance to the group's repertoire, and that (2) 'earlier the group's management gave promises that the service would be expanded to Sweden and Finland'. The group's management remains undefined and the promise unspecified.

\section{The Restructured Company Faces Specific Future Challenges}

In addition to the body of the article, the other text bundle analysed here is Matti Kankare's column 'Targeted advertising to nine million', together with the picture of a customer at a Solo ATM. As a genre, the text can be defined as a column, representing subjective reporting. The column can be seen as a dialogue between executives of the bank group. Intertextually speaking, the citations of the executives are explicit references to the policy of the bank. 
The column is thus also a dialogue between the financial supermarket's policy (with the executives as intermediaries) and the viewpoints of the writer. The impression of a dialogue is based, on the one hand, on the rhetorical structure of the column, and, on the other, on the writer's linguistic choices. Three key people dominate the text: executives Hans Dalborg and Bo Harald, and the former executive Kalevi Kontinen. Their presence frames the column.

In the dialogue, the journalist makes his own opinions explicit by use of the executives' statements. He divides the text rhetorically into three sections, each of which refers to one of the bank's executives, e.g. 'Hans Dalborg says . . .'; 'Earlier the group's management gave promises to the effect that the service would be expanded to Sweden and Finland'. These references are followed by the writer's personal evaluative comments, such as 'The CEO's words reflect a conciliatory approach towards the Danes'. It is thus evident that the relation observed between the body (nucleus) and the column (satellite) is evaluation. There is variation in the commentaries in respect of modality. At times it is a modal adjunct or an auxiliary verb that conveys the opinion of the writer: 'This targeted service and marketing concept may well work ...'At other times it is a relational process that plays the main role: 'The risk is that nobody knows whether Nordic consumers will reject targeted marketing'; 'There'll certainly be plenty of work ahead for the financial giant . . . These opinions are at the same time speculations about the future challenges to the bank group. These challenges are stated by the journalist in an accumulation of mental processes (such as 'know', 'understand'; see Halliday, 1994). Interestingly, all six mental processes of this column elaborate the textual theme of risk:

The risk is that nobody knows whether Nordic consumers will reject targeted marketing. In the US, consumers have easily accepted detailed market analyses made of them by companies, but they don't like using Internet banks. In Europe, the situation is just the reverse. The huge rise of electronic banking services is a lesson to older Merita shareholders. In approving the merger, the shareholders scarcely understood the enormous importance of the Solo electronic banking services to the future of the bank.

The column also portrays visions of the future of the bank group, mapping out potential risks and success factors. It is arguing for the opinions of the writer. These functions of the text are all identifiable in the writer's particular linguistic and rhetorical choice: the use 
of numbers. There are ' 8.5 million personal customers and 450,000 small and 500 major corporate customers' of the bank; the bank 'already has FIM 600 billion of its customers' assets'; the number of on-line customers at Unidanmark should be raised from '170,000 to well over one million'; 'MeritaNordbanken's customers pay about 3.7 million bills a month over the Internet'; 'the proportion of share trading in Finland over the Internet has reached as much as 61 per cent'; 'the corresponding figure for fund investments has been 10 per cent'.

Numbers explicate the goals for the new Nordic financial supermarket. They also make it possible to compare the different Nordic country units of the bank group. In this sense, the figures are realizations of both rationalistic and nationalistic discourses. The Finnish reader is tempted to conclude that Finns are leading the way and the Danes are following (see also the next section of this paper). This interpretation is confirmed by the caption to the picture attached to this text. As mentioned above, in this column the writer constructs a dialogue between himself and the executives. This enables evaluation. In addition, another relation can be seen between the nucleus and this particular text, that of interpretation. Arguably, the whole column is an interpretation of the new merger situation, especially in relation to the future behaviour of customers.

The picture attached to the column is rhetorically significant. The number of customers mentioned in the heading-'nine million'-implies a mass. This is in contrast to the picture, which depicts an individual - in the future a Dane will have the 'delight' of making transactions via an ATM and also by the Internet. This illustration is evaluative in many respects, and its multimodal communication is persuasive rather than convincing.

\section{International Confrontation Is Taking Place}

Given the particular audience of the article - the readers of a weekly business magazine - the emphasis on the financial rationale is not surprising. What is noteworthy, however, is the prevalence of nationalistic discourse. Organizations and key individuals are introduced and treated as representatives of specific nationalities. In the body of the article, the nationalities theme attracts specific meanings. For example, the Danes as a nation are labelled 'wealthy'. This is given as justification for their representative to be in charge of asset management in the new financial supermarket. At the same time, Danes (i.e. Unidanmark) are advised to 'lose some weight', to become more efficient and/or downsize to meet the cost to income ratio of MeritaNordbanken, i.e. the Finns and Swedes. 
Finns, in turn, are presented as being in the global forefront of Internet banking. Finnish readers are likely to recognize this from earlier texts, and perhaps also associate Merita with Finland, which has been labelled an information technology society (see Castells and Himanen, 2001). The relatively ambiguous theme of Internet banking, then, becomes legitimized by its links to a representation of reality likely to be socially acceptable to Finnish readers, that is, Finland as a 'nation' succeeding in the global economic and business arena by pursuing the opportunities provided by information technology.

Rhetorically, the descriptive, attitudinal, entertaining and metaphoric use of language can be interpreted as persuading the reader. On the one hand, it attracts the reader to go further into the text. On the other, the writer persuades the reader to take the same stance as him on the subject matter. Nationalistic discourse is evident: 'us' Finns versus 'them'; Danes appear here most explicitly as 'them' in the international confrontation. This is present in the picture of a customer using a Solo ATM. Interpreting the picture textually, the theme of the caption-the Finnish Solo electronic banking service-is attached to the rheme-new information - which is 'delight' in a way that contrasts the banking systems in Finland and Denmark. Electronic banking is new for the Danes, as is Internet banking (' . . the Danes, to whom on-line banking is still something new'). From now on, however, Solo will 'delight the customers of Unidanmark in Copenhagen'.

This particular section could also be interpreted ironically. The picture to which the caption is attached portrays a customer using an ATM outdoors. The customer appears warmly clothed. The picture may then be associated with the public discussion in Finland on the position of customers after the merger of the Kansallis Bank and the Union Bank of Finland (which formed Merita Bank in 1995). Cuts in personnel, leading to a deteriorating service, have been criticized in the Finnish media. Banks were accused of 'throwing' customers out of bank branches - to use ATMs, for example.

From the perspective of rhetorical structure theory, it is also important to note the table captioned 'Lose some weight, Danes' in the middle of the collage. In brief, there are two contrasting relations in the table: one relates the table to the body of the article and the new Nordic Bank; the other is within the table. The table effectively contrasts the financial situation of the national units in the bank group, showing that they are not equally efficient. Rhetorically, contrast offers various alternatives (Mann, 1999). The alternative seen in the Danish figures is not up to standard. The table thus suggests that Unidanmark (Denmark) 
needs to reduce its personnel, as has already been done in Merita (Finland) and Nordbanken (Sweden). It is noteworthy that only five pieces of information have been detached from the entire profit and loss account. The linguistic choices made by the writer in the table thus show that arguing and convincing are most effective when the reader is construed to be at the same level of knowledge as the writer, in this case, acquainted with the principles of accounting.

\section{Personal Power Battles Are an Essential Part of Restructuring}

We have already observed that the information in the body of the article is conveyed mainly by material and relational processes, by which the writer focuses on two dominant messages: the inevitability of the 'merger storm' and the core business of the new bank group (a financial supermarket). There is, however, a process type that has been used selectively, namely mental processes. These processes of the human mind (such as 'accept', 'reject'; see Halliday, 1994), together with the text in the table, are obvious deviations stylistically. They may be interpreted as colouring the text, even entertaining the reader, as far as this is possible in an article in a business magazine. These mental processes can be observed in the reconstruction of international confrontation. They are, however, especially central in the personification of the merger drama. This is illustrated by the following: 'the management team will be monitoring it [general insurance]'; 'the Danes should not be provoked'; 'Voutilainen is already pondering his retirement'; 'Carl-Johan Granvik will be in charge of loans'; 'the markets are ... confident'.

Rhetorically, mental processes enable the colouring and personificationof otherwise factual text. They thus make it easier to communicate the issues at hand. Mental processes can be interpreted as being interpersonal, seeking contact with the reader. Humour, too, can be interpreted in these processes. The process of Pertti Voutilainen 'already pondering his retirement' is humorous in the immediate context of the picture, where there are managers who 'will be in charge of loans' and who are 'smiling on the screen behind'. The humorous interpretation is motivated by the Finnish readers' historical knowledge of Voutilainen's role in Merita Bank and earlier in Kansallis Bank. For a number of years, some business journalists have been speculating on Voutilainen's retirement in an extremely harsh manner (Kuronen et al., 2000). 
In the system of rhetorical relations, the satellite (the picture) is, first, elaborating on the nucleus by giving additional information (see Mann, 1999). The picture and its caption also evaluate the situation. The positions of the executives in the front and at the back suggest distinct relations between them. However, so little information is provided by this picture (and the caption) that it makes the observer wonder whether the picture is, in the name of persuasion, merely entertainment. As discussed above, it is evident that, for the claims and meanings to be conveyed in the article, it is important that the persons involved in the drama represent distinct nationalities. Otherwise, the text would not 'work'. The executives in the picture interlink the various themes in the article with nationalistic discourse. The message conveyed is thus personified (see Vestergaard, 2000; Fairclough, 1995).

\section{Discussion: Understanding the Broader Significance of the Rhetorical Constructions}

In our empirical analysis of an article in a weekly business journal, we have focused on the rhetorical construction of key arguments put forward by the two journalists. To understand the broader significance of these constructions, it is interesting to note that the article appeared under the label of 'news'. Yet, as shown above, it can be argued to be a clear example of non-news because it carries comments, interpretations, evaluations and recommendations (see Fowler, 1991; Vestergaard, 2000). The article appears to be a hybrid text that illustrates a blurring of genres in contemporary media (see Fairclough, 1995).8

As is usually the case with (individual) media texts, the rhetorical constructions do not seem particularly surprising or frame-breaking (see Bourdieu, 1998). Rather, they seem to confirm existing presuppositions by particular audiences. It is, however, precisely this confirmatory nature of the construction of arguments that is interesting in the broader picture. By constructing arguments that are coherent with existing presuppositions, pieces of text, such as the one on which we focus, legitimate and naturalize specific ideas and ideologies.

Each of the five arguments is an important element in the discursive legitimization and naturalization of international industrial restructuring. As to the first argument, the rationale of industrial restructuring no longer requires specific justification in each text, not even in a two-page 'collage' that takes up a relatively large amount of space in the journal. The present situation is a natural follow-up to earlier events (see Kuronen et al., 2000). Our systemic functional analysis clearly points out how the journalist conveys the theme of continuous mergers through dynamic material processes, whereas the picture is 'frozen' when 
discussing the management and business in question - the situation is described by strong claims and relational processes ('general insurance is an odd business'). Even the column headed 'Targeted advertising to nine million', with its apparently precise figures ('facts') and descriptions of modern banking, is not an argument for the merger in question, but a warrant (see Rieke and Sillars, 1984): Internet banking makes business more efficient, and efficiency is a sufficient argument for a merger. This is clear evidence that the cross-border merger as such has already become naturalized. The rhetorical construction of inevitability, specified above, is then about convincing readers about the conditions and circumstances of mergers, not about industrial restructuring through cross-border mergers and acquisitions per se.

With regard to the second argument, it is interesting to note how strongly core business thinking is put forward by the journalists as the appropriate restructuring strategy. This is mainly achieved by questioning the current diversified nature of the 'financial supermarket'. This is a very clear example of the journalists' criticizing an arrangement that does not seem to fit with a dominant ideology. Historically speaking, it is interesting to note that it is only during the past two decades that core business thinking in general has become dominant, resulting in waves of 'related' mergers and acquisitions (Jansen, 2002). During the 1960s and 1970s the dominant ideology in corporate strategy was diversification. This was reflected in a wave of mergers and acquisitions between companies operating in different industries. In all, what is taken as legitimate and natural is history specific-something that usually passes unnoticed in the media.

The third argument put forward by the journalists in the analysed article constructs a picture of specific 'future challenges'. Although the new group will undoubtedly face many kinds of challenge in the future, it is interesting that particular challenges are given a lot of attention whereas others are ignored. Issues such as efficient marketing ('targeted marketing', which may be 'rejected' by customers), the spread of Internet banking concepts, and the ability to streamline operations are the focus of the 'rationalistic' discourse employed here. At the same time, the concrete human aspects of the restructuring are notably absent. As is often the case with these kinds of media text, the specific concerns of employees relating to unemployment, increased workload, career opportunities and identity problems are subordinated by the 'rationalistic' rhetoric. Employees are merely constructed as the 'weight' that the Danes are advised to 'lose'. 
In the case of the fourth argument, our analysis shows how the crossborder merger is (re)constructed as international confrontation. This means that the journalist (re)invents nationalism as a banal discursive framework through which readers can make sense of crossborder business manoeuvres (see Billig, 1995; De Cillia et al., 1999; Hellgren et al., 2002; Risberg et al., 2003). This (re)construction of nationalism provides the journalist with an opportunity to create interpersonal relationships and make contact with the reader (of a particular nationality) but at the same time revitalizes a specific discourse whose ideology is not entirely consistent with the assumed rationality and neutrality of the dominant global capitalism discourse. This inconsistency is, however, masked because in this type of situation the reader (of a particular nationality) is usually unable to grasp the picture created by the media 'on the other side'.

Finally, with regard to the fifth argument, it may seem self-evident that personified power struggles are a key feature of contemporary business texts (see Fairclough, 1995; Vestergaard, 2000). It is, however, important to note that the mental processes and interpersonal contacts in personification lead to the construction of mergers and acquisitions as dramas in which particular people-either as individuals or as representatives of certain social groups - become winners, losers, heroes or scapegoats (see Vaara and Tienari, 2002; Hellgren et al., 2002). One consequence of this is that it becomes possible to deal with international industrial restructuring, with all its complex long-term economic, societal, cultural and human consequences, also as an entertaining phenomenon-even involving the celebrity culture (see Fairclough, 1995). And, as pointed out above, our analysis of rhetorical relations confirms the notion that the genre of news in a weekly business magazine does not exclusively involve 'objective' reporting on current events, but also includes 'subjectively' convincing and persuading through evaluation, interpretation and entertainment (see Vestergaard, 2000). Convincing with 'facts', it seems, needs to be complemented by persuasion of readers with more colourful elements.

\section{Conclusion}

Despite the central role of the media in contemporary society, studies examining the rhetorical practices of journalists are rare in organization and management studies. In this paper, we have examined the discursive (re)construction of a business manoeuvre from a rhetorical perspective. We have proposed a theoretical framework for analysing the micro strategies and techniques in the rhetorics of journalists. This framework combines systemic 
functional grammar (Halliday, 1978, 1994; Eggins, 1994; Martin, 2000), rhetorical structure theory (Mann and Thompson, 1988; Mann et al., 1992) and critical discourse analysis (Fairclough, 1992, 1995, 1997). With this three-fold framework, we have engaged in a process of analysis that has coherently explored the prominent discourse types in a media text, the strategic meaning-making functions within these discourse types, and key rhetorical choices and strategies working to persuade and convince the reader. This integrative approach has enabled us to illustrate and specify how journalists (re)construct what is legitimate and natural.

In our analysis, we have illustrated how specific arguments are rhetorically constructed through a skilful (but perhaps not always conscious) use of various discourses, strategic meanings and rhetorical structures. As is often likely to be the case with articles of this type, the arguments tend to be built on existing widely held presuppositions and confirm rather than challenge existing ideas and ideologies (see Fairclough, 1997). In the article we analyse, this is clearly visible in that the journalists' rhetorical strategies and techniques involve convincing (i.e. approaching a universal audience) more than persuasion (i.e. addressing a specific audience) (see Perelman and Olbrechts-Tyteca, 1971). This points to the central role of convincing in the discursive legitimization and naturalization of management ideas and ideologies. Nevertheless, the persuasive elements also play an important role in the text. For example, entertaining elements - in this case also humour and irony-are used to catch the attention of the audience.

From a critical perspective, our analysis gives rises to several points. The analysed article is an example of journalists reinforcing dominant ideologies with case-specific commentaries. As long as the strategies of the companies and the ideas and actions of the key managers involved correspond to the dominant ideology, the journalists appear to echo the managers' viewpoints. However, when the strategies and actions appear to deviate from the dominant norms, the journalists seem to be able to exercise some kind of disciplinary power. For example, in our case, the journalists criticize the diversified nature of the restructured company ('financial supermarket'). This is not to say that journalists would not also work as critical observers and at times challenge the dominant ideologies. What we are arguing is that most often journalists are caught up with the existing presuppositions or commonplaces when trying to establish contact with their readers, to make the text 'work' (see Bourdieu, 1998). 
In our view, the detailed, integrative linguistic framework developed above has specific advantages in studying media texts. First, the research is carried out 'bottom up'. The analysis pays attention to explicitness, to the actual choices made by the writer, which are visible in the text. Hence, the premise is that we as researchers are not, for example, specifically searching for the meaning potential of power or status asymmetries. If, through a 'close reading' of the text, we find traces of this, such interpretations constitute part of our findings rather than our point of departure. Second, at a later stage in the 'bottom up' analysis, the language use choices in the studied text-as well as the rhetorical and linguistic structuring — can be attached to (pragmatic) presuppositions. This integrates the analysis to the sociocultural context.

There are, however, also other interesting methods that could be used when going further in critical analyses of the social construction of contemporary management ideas and ideologies at the micro level. Deconstruction as a methodology is particularly well suited to critical analysis, and it has also been used successfully in various ways in organization and management research. Jacques Derrida's ideas on deconstruction have been applied to provide alternative 'readings' of classic pieces in organization theory (e.g. Kilduff, 1993). For feminist organization theorists, deconstruction has provided a means to unpack gender assumptions and practices in social texts (e.g. Martin, 1990; Cal'as and Smircich, 1999). As a philosophically grounded methodology, deconstruction opens up possibilities to dig deeper into 'unsaid' elements by analysing the exclusions on which writers need to rely in order to represent a particular 'reality'. Future studies could draw on this methodology to help us understand the ideological implications of particular discursive conventions and specific discursive strategies used by journalists.

In conclusion, from the perspective of critical organization and management research, the main implication of our analysis is that it illustrates the rhetorical power of the media. With the suggested theoretical framework for studying the rhetoric of journalists and with an explicit focus on a media text, we have attempted to add to recent contributions that have made explicit the discursive constitution and underlying rhetorical strategies in organizing and managing (e.g. Alvesson, 1993; Watson, 1995; Case, 1999; Berglund and Werr, 2000). It is not only managers who contribute to the legitimization and naturalization of specific management ideas and ideologies. Journalists may become significant 'spokespersons' in transmitting and translating dominant ideas and ideologies to different audiences. 


\section{Nordic Union Bank 60}

BEYOND FRONTIERS

It is clear that the Norwegian

Kreditkassen will join

MeritaNordbanken and

Unidanmark. Before

the end of the year

there will be a new

Nordic Union Bank that

will be bigger than

before.

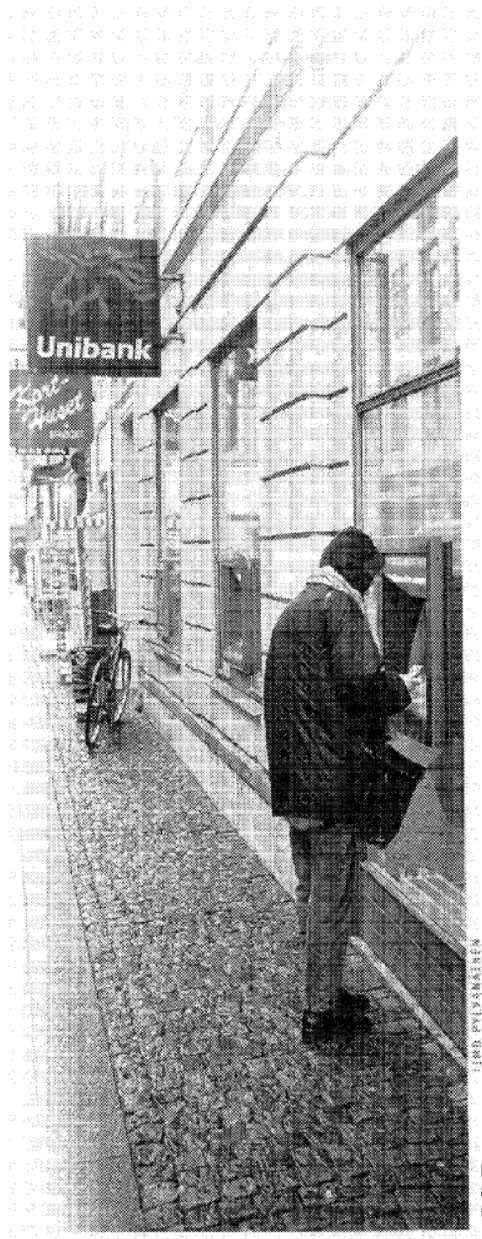

A storm of banking and insurance Unidanmark actually used general mergers is raging across Europe. insurance as a means to puff itself Finland's Merita will get better MeritaNordbanken and thus obtain head-start, when the Danish a 30 per cent share of the new Unidanmark unites with the joint financial group.

Swedish-Finnish Nordic Baltic

Holding Banks in the Nordic Finnish management is strong countries have been merging The growth areas of the new across national boundaries for financial group will be new many years now. In continental management and electronic Europe this agony is still to banking services. The wealthy
come. com The current creation of management, with Christian will also more obviously be a function. Merita's

'financial supermarket'. The business concept behind the In the Nordic December Unidanmark bought banking and company Vesta. General insurance is an odd business for a insurance sector financial group specialising in financing and investment mergers and services

Whether or not general insurance acquisitions of remains in the group will depen on its capital return, explains chief executive. The management team will be monitoring it in the same way as the other areas of its business.

In the Nordic banking and insurance acquisitions of recent years, general insurance has customarily flown out.

This was the case, for example, when SE-Banken acquired TryggHansa. The major corporate general insurance customers were taken by Zürich Financial and the
private customers and small private customers and small companies by the Danish by the UK insurance giant Royal by the UR insurance giant Royal
$\&$ Sun Alliance. \& Sun Alliance.

The partnership composed of Skandia, the Norwegian turned its generol insola also tured its general insurance into a here, life and did not fit under the same roof. The global trend has long been to separate life and insurance into completely different companies. It's possible that before long we may see If buying up the general insurance business of the joint Nordic bank. The Danes should not be selling general insurance, because

The Finnish Solo will come and relight the customers of Unidanmark in Copenhagen.

recent years,

general insurance

has customarily

flown out.

\section{BANK MERGER}

Group CEO Hans Dalborg says that the data of the new bank's 8.5 million personal customers and 450,000 small and 500 major corporate customers will be held on one of the most comprehensive databases in the Nordic countries.

\begin{tabular}{|c|c|c|}
\hline & $\begin{array}{c}\text { Merita } \\
\text { Nardbanken }\end{array}$ & $\begin{array}{l}\text { Uniden } \\
\text { mark }\end{array}$ \\
\hline Balance (EUR billion) & 104 & 77 \\
\hline Operating profit (EUR) & 1383 & 696 \\
\hline Return on equity $(\%)$ & 20.9 & 15.2 \\
\hline Cost to income ratio $(\%)$ & 1.55 & 69 \\
\hline Personnel & 18800 & 14500 \\
\hline
\end{tabular}

Bo Harald will retain hold of the Internet banking reins.

Finns will be well represented in of the Board for the Chairman years will be Vesa Vainio while Markku Pohjola will look after corporate and institutional banking, and Carl-Johan Granvik takes charge of credit and risk management Kari Jordan will be head of retail banking in Finland. The IT director's seat is vacant following the departure of Kalevi Kontinen. Dalborg of Nordbanken took the position of Group CEO, with the Dane Thorleif Krarup as Deputy

Finland will be the strongest market for the new Nordic bank: in retail banking the bank's share of the Finnish market is 35 per cent, compared to 20 per cent in Sweden and 23 per cent in

MeritaNordbanken is growing fast and is profiability has improved greatly. Unidanmark, on the other mergers behind it: first with the local Tryg-Baltica insurance local Tryg-Baltica insurance the Norwegian general insurance company Vesta last December. The Unidanmark group's return on equity last year was
15 per cent, whereas MeritaNordbanken round almost 21 per cent. Major IT investments were one reason behind the high costs at Unidanmark, and the company experienced a fall in its operating profit on core operations. This year
Unidanmark

\section{Targeted advertising to nine million}

The database will allow the bank to target its financial services and life and general insurance services at selected customers. This targeted service and marketing concept may well work, as the bank already has FIM 600 billion of its customers' assets.

Unidanark will add to the group's repertoire 


\section{mplete but for Norway}

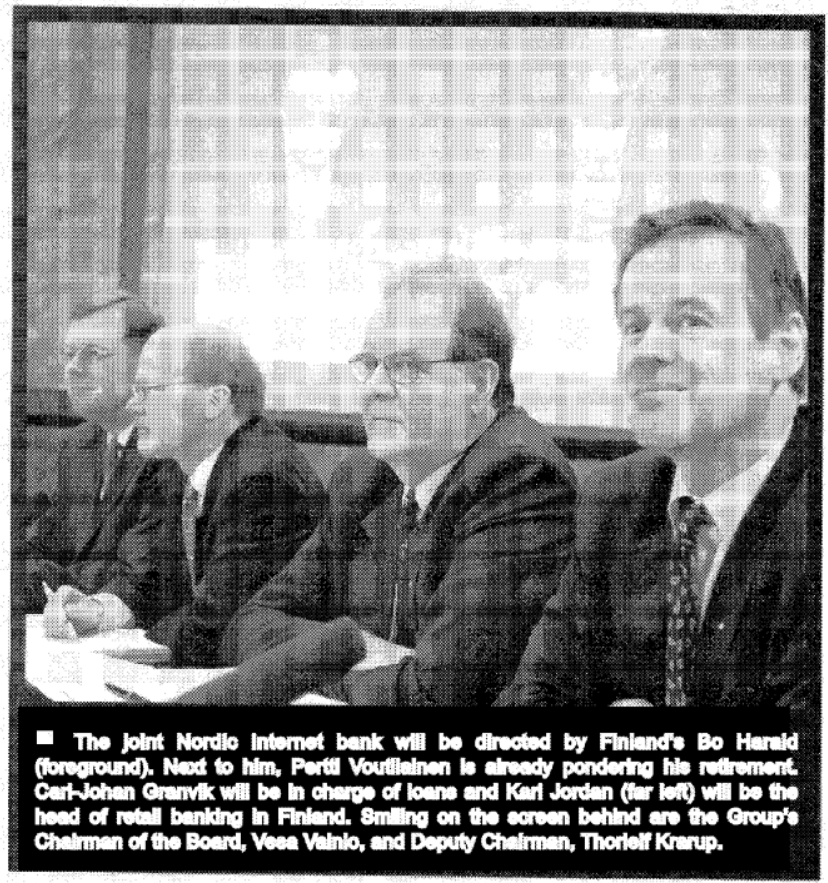

\section{Bank mergers no longer recognize borders}

wermany's largest and third largest banks Deutsche Bank and Dresdner Bank, are keen to join forces. This would create not only the year Deutsche Bank bought the US company

The Spanish bank Banco Santander Centra Hispano announced on Tuesday that it had Mayor and insurance company Mundial Confianca.

In February, in a hostile takeover, Royal Bank of Scotland took control of one of the City's major, long-established commercial banks. NatWest.

Last autumn, the Wallenbergs' SEB bank acquired the German bank BfG, which it announced it would develop as an internet and asset management bank. One of the sellers was the French Crédit Lyonnais, which underwent a major profitability crisis in the

In August 1999, the French BNP and Paribas joined forces. The third name to emerge in the merger speculation was Société Générale, which is still struggling to remain independen The Dutch 'financlal supermarket' ING purchased the German BHF bank last year. And a year ago Den Danske Bank acquired the Norwegian Fokus Bank

has budgeted for a rise of 20 per that Norway's Kreditkassen will a one-third holding in Kreditkassen, If MeritaNordbanken's current bid cent in its operating profit, and the join the Swedish-Finnish-Danish while MeritaNordbanken now has a of FIM 17.5 billion for general insurance Vesta will bring financial group. On Tuesday slice of almost 10 per cent - indeed, Kreditkassen succeeds, a cash offer in a considerable share of this Meritassen's valuation excee

The markets are increasingly MeritaNordbanken's offer price. more than this. would enable it to take control of Unidanmark.

ESKO RANTANEN

not only life and pension insurance but also its full general insurance Denmark. Eatier the and mennarke manace Sweden and Finland expanded to The risk is that

we nobody knows reject taroeted marketing US, consumers have In the accepted detailed market analyses made of them by companies, but they don't like using Internet banks. In Europe, the situation is just the reverse.

The huge rise of electronic banking services is a lesson to older Merita shareholders. In approving the merger, the shareholders scarcely understood the enormous importance of the Solo electronic banking

The Solo services, begun by forme The solo services, begun by former with Nokia), were exported with Nokia), were exporte cheaply to Sweden and will now go

On the other hand, the Danes have now been brought into the join plenty of work ahead for the financial giant when it raises the number of on-line customers at Unidanmark from the prosent 170,000 to MeritaNordbanken aims to increase about 3.7 million bills a month MATTI KANKARE year.
According to Dalborg, the role of The proportion of share trading in the Internet bank will increase as e- Finland over the Internet has becomes more reached as much as 61 per cent widespread. It will not be made the corresponding figure for fund into a separate unit, however, investments has been 10 per cent. because of its close links with Almost 16 per cent of loan "We services at branch offices. applications are already submitted banking pexing service to exclude the destroyed the previous conception personar contact avallable to that personal contact is al istor " confirms CEO's words reflect a conciliatory banking services, predicts that by whom towards the Danes, to the end of 2000 he proportion of whom on-line banking is still loan applications submitted on-line Merits over the Internet. 


\section{Notes}

The authors' names are given in alphabetical order.

1 The concept of rhetoric has been put to use in management and organization studies in a multiplicity of ways. Many researchers appear to distinguish between the 'rhetoric' and 'reality' of organizational phenomena (Brunsson, 1989; Zbaracki, 1998). The concept of rhetoric has also been used when the content and form of management ideologies, ideas and techniques have been examined historically (Abrahamson, 1997; Barley and Kunda, 1992; Kieser, 1997).

2 Halliday's thinking builds to a great extent on the work of Firth (1957), especially his system-structure theory. Halliday has adopted more abstract ideas from, for example, the Prague school of linguists. The anthropologist Malinowski's (1923/1985) concepts of cultural and situational contexts have also influenced the development of systemic functional theory.

3 Referring to language as a semiotic system - a conventionalized coding system,organized as sets of choices (Eggins, 1994: 3).

4 Other relations between spans of texts are background, elaboration, preparation, contrast, motivation, concession, circumstance, purpose, non-volitional result, restatement, sequence, solutionhood, condition, evaluation and interpretation (Mann, 1999).

5 Finnish readers are, however, evidently expected to know what 'Wallenbergs' SEB' stands for. The Wallenberg family is the most influential business and industry dynasty in Sweden.

6 The label 'financial supermarket' has been used extensively in the Finnish media since the late 1980s. The audience of a business magazine can be expected to associate this metaphor with a company that is engaged in both banking and insurance.

7 'If' is a new Nordic general insurance company.

8 The article analysed is inter-discursive. It is an expository text in describing a problem and proposing solutions, but it is also hortatory, aiming to get the reader to accept the proposed solutions. Vestergaard (2000) calls texts that combine features of expository and hortatory texts persuasive. 


\section{References}

Abrahamson, E. (1997) 'The Emergence and Prevalence of Employee Management Rhetorics: The Effects of Long Waves, Labor Unions, and Turnover, 1875 to 1992', Academy of Management Journal 40: 491-533.

Alvesson, M. (1993) 'Organizations as Rhetoric: Knowledge-Intensive Firms and the Struggle with Ambiguity', Journal of Management Studies 30: 997-1015.

Barley, S. R. and Kunda, G. (1992) 'Design and Devotion: Surges of Rational and Normative Ideologies of Control in Managerial Discourse', Administrative Science Quarterly 37: 363-99.

Berglund, J. and Werr, A. (2000) 'The Invincible Character of Management Consulting Rhetoric: How One Blends Incommensurates while Keeping Them Apart', Organization 7: 633-55.

Billig, M. (1995) Banal Nationalism. London: Sage.

Bourdieu, P. (1998) On Television. New York: New Press.

Brunsson, N. (1989) The Organization of Hypocrisy: Talk, Decision and Actions in Organizations. Chichester: Wiley.

Cal'as, M. B. and Smircich, L. (1999) 'Past Postmodernism? Reflections and Tentative Directions', Academy of Management Review 24: 649-71.

Case, P. (1999) 'Remember Re-engineering? The Rhetorical Appeal of a Managerial Salvation Device', Journal of Management Studies 36: 419-41.

Castells, M. and Himanen, P. (2001) The Finnish Model of Information Society. Helsinki: Sitra.

De Cillia, R., Reisigl, M. and Wodak, R. (1999) 'The Discursive Construction of National Identities', Discourse and Society 10: 149-73.

Eggins, S. (1994) An Introduction to Systemic Functional Linguistics. London: Continuum.

Fairclough, N. (1992) Discourse and Social Change. Cambridge: Polity Press. 
Fairclough, N. (1995) Media Discourse. London: Edward Arnold.

Fairclough, N. (1997) Critical Discourse Analysis: The Critical Study of Language, 2nd edn. London: Longman.

Fairclough, N. (2000) ‘Guest Editorial: Language and Neo-liberalism', Discourse and Society 11: $147-8$.

Firth, J. R. (1957) Papers in Linguistics 1934-1951. London: Oxford University Press.

Fowler, R. (1991) Language in the News. London: Routledge.

Gowler, D. and Legge, K. (1983) 'The Meaning of Management and the Management of Meaning: A View from Social Anthropology', in M. J. Earl (ed.) Perspectives on Management. Oxford: Oxford University Press.

Halliday, M. A. K. (1978) Language as Social Semiotic: The Social Interpretation of Language and Meaning. Baltimore, MD: Edward Arnold.

Halliday, M. A. K. (1994) An Introduction to Functional Grammar, 2nd edn. London: Edward Arnold.

Hellgren, B., L“" owstedt, J., Puttonen, L., Tienari, J., Vaara, E. and Werr, A. (2002) 'How Issues Become $(\mathrm{Re})$ constructed in the Media: Discursive Practices in the AstraZeneca Merger', British Journal of Management 13(2): 123-40.

Jansen, S. A. (2002) 'Pre- and Post-merger Integration in Cross Border Transactions: Trends, Tools, Themes and Empirical Tests of Old and New Economy Deals', in G. Picot (ed.) International Handbook of Mergers and Acquisitions. London: Palgrave.

Kamoche, K. (1995) 'Rhetoric, Ritualism, and Totemism in Human Resource Management', Human Relations 48: 367-85.

Kieser, A. (1997) 'Rhetoric and Myth in Management Fashion', Organization 4: 49-74.

Kilduff, M. (1993) 'Deconstructing Organizations', Academy of Management Review 18: 1331. 
Kress, G. and van Leeuwen, T. (1996) Reading Images: The Grammar of Visual Design. London: Routledge.

Kuronen, M.-L., Tienari, J. and Vaara, E. (2000) “"Will Merita's Jungle Adventure Come to an End?": Interpretations of a Linguist and an Organizational Researcher on the Social Construction of Change in the Media', Viritt “ aj “a 4: 518-41 (in Finnish).

Legge, K. (1995) Human Resource Management: Rhetoric and Reality. London: Macmillan.

Linstead, S. (2001) 'Rhetoric and Organizational Control: A Framework for Analysis', in R. Westwood and S. Linstead (eds) The Language of Organization. London: Sage Publications.

Malinowski, B. (1923/1985) 'The Problem of Meaning in Primitive Languages', Supplement 1, in C. Ogden and I. A. Richards The Meaning of Meaning. New York: Harcourt Brace.

Mann, B. (1999) An Introduction to Rhetorical Structure Theory (RST). URL: http://www.sil.org/linguistics/RST/rintro99/ht

Mann, W. C. and Thompson, S. A. (1988) 'Rhetorical Structure Theory: Toward a Functional Theory of Text Organization', Text 8: 243-81.

Mann, W. C., Matthiessen, C. M. I. M. and Thompson, S. A. (1992) 'Rhetorical Structure Theory and Text Analysis', in W. C. Mann and S. A. Thompson (eds) Discourse Description: Diverse Linguistic Analyses of a Fund-raising Text. Philadelphia, PA: John Benjamins.

Martin, J. (1990) 'Deconstructing Organizational Taboos: The Suppression of Gender Conflict in Organizations', Organization Science 1: 339-59.

Martin, J. R. (2000) 'Close Reading: Functional Linguistics as a Tool for Critical Discourse Analysis', in L. Unsworth (ed.) Researching Language in Schools and Communities. Functional Linguistic Perspectives. London: Cassell.

Mazza, C. and Alvarez, J. L. (2000) 'Haute Couture and Pret-`a-Porter: The Popular Press and the Diffusion of Management Practices', Organization Studies 2: 567-88.

O’Toole, M. (1994) The Language of Displayed Art. London: Leicester University Press. 
Perelman, C. (1977/1996) Retoriikan valtakunta. Jyv“askyl“a, Finland: Vastapaino. (L'Empire rh'etorique. Rh'etorique et argumentation. Paris: Librairie Philosophique J. Vrin, 1977.)

Perelman, C. and Olbrechts-Tyteca, L. (1958/1971) The New Rhetoric: A Treatise on Argumentation. Notre Dame: University of Notre Dame Press. (La Nouvelle rh étorique: Trait 'e de l'argumentation. Paris: Presses Universitaires de France, 1958.)

Rieke, R. D. and Sillars, M. O. (1984) Argumentation and the Decision Making Process, 2nd edn. Glenview, IL: Scott, Foresman.

Risberg, A., Tienari, J. and Vaara, E. (2003) 'Making Sense of a Transnational Merger: Media Texts and the (Re)construction of Power Relations', Culture and Organization 9(2): 121-37.

Vaara, E. and Tienari, J. (2002) 'Justification, Legitimization and Naturalization of Mergers and Acquisitions: A Critical Discourse Analysis of Media Texts', Organization 9: 275304.

Vestergaard, T. (2000) 'That's Not News: Persuasive and Expository Genres in the Press', in Anna Trosborg (ed.) Analysing Professional Genres, pp. 97-119. Amsterdam/Philadelphia: John Benjamins.

Watson, T. J. (1995) 'Rhetoric, Discourse and Argument in Organizational Sense Making: A Reflexive Tale', Organizational Studies 16: 805-21.

Zbaracki, M. J. (1998) 'The Rhetoric and Reality of Total Quality Management', Administrative Science Quarterly 43: 602-36. 